\title{
The Duty of States to Assist Other States in Need: Ethics, Human Rights, and International Law
}

Lawrence O. Gostin

Georgetown UniversityLaw Center, gostin@law.georgetown.edu

Robert Archer

International Council on Human Rights Policy, archer@ichrp.org

This paper can be downloaded free of charge from:

http://scholarship.law.georgetown.edu/ois_papers/7 


\title{
GEORGETOWN UNIVERSITY
}

\section{O’Neill Institute for National \& Global Health Law Scholarship}

Research Paper No. 7

February 2008

\section{The Duty of States to Assist Other States in Need: Ethics, Human Rights, and International Law}

\author{
Lawrence O. Gostin \\ Associate Dean (Research and Academic Programs) \& The Linda D. and Timothy J. O’Neill \\ Professor of Global Health Law \\ Georgetown University Law Center \\ gostin@law.georgetown.edu \\ Robert Archer \\ Executive Director \\ International Council on Human Rights Policy \\ archer@ichrp.org
}

35 Journal of Law, Medicine \& Ethics 526 (2007)

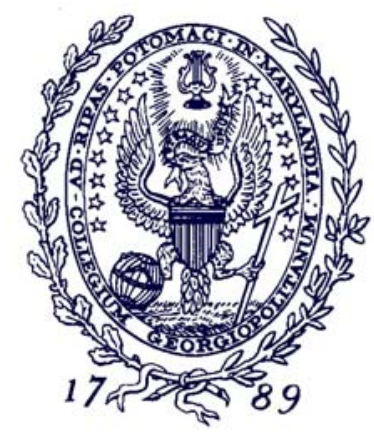

This paper can be downloaded without charge from:

http://ssrn.com/abstract $=1095769$

http://lsr.nellco.org/georgetown/ois/papers/7

Posted with permission of the authors 
The Duty of $\quad$ T States to Assist Other States in Need: Ethics, Human Rights, and International Law

\author{
Lawrence O. Gostin and \\ Robert Archer
} high levels of need affecting the health and life of their citizens? The question is important for a variety of reasons. There exist massive inequalities in health globally, with the result that poorer countries shoulder a disproportionate burden of disease and premature death. Average life expectancy in Africa is nearly 30 years shorter than in the Americas or Europe. ${ }^{1}$ In one year alone, an estimated 14 million of the poorest people in the world died, while only an estimated four million would have died if this population had the same death rate as the global rich. ${ }^{2}$

While poor countries have by far the greatest ongoing health needs, they also have the least capacity to meet those needs. The least developed countries spend between $\$ 1$ and $\$ 25$ per capita per year on health whereas developed nations spend between $\$ 1,500$ and $\$ 5,000 .^{3}$ The Organization for Economic Co-operation and Development (OECD), which compares trends among 30 industrialized countries, shows that the U.S. spends more than $\$ 5,000$ per capita on health care - greater than 50 percent more than any other country.

In addition to the pervasive and debilitating effects of endemic disease, developing countries are likely to suffer much more from the effects of acute health hazards, ranging from natural disasters (such as the South Asian tsunami) and dislocations (due to civil unrest, violence, and war), to emerging infectious diseases such as highly pathogenic avian Influenza (A) H5N1. The least well-off countries will suffer most in a public health emergency because they do not have the health infrastructures, vaccines, and essential medicines that are available to developed countries. Pandemic influenza plans in most developed countries, for example, rely on stockpiling vaccines and antiviral medications, which are out-of-reach to the developing world. ${ }^{4}$ In conditions of extreme scarcity, the countries that are most likely to gain access are those that manufacture medical countermeasures and have the resources to purchase expensive vaccines and medicines. $^{5}$

Lawrence O. Gostin, J.D., LL.D., (Hon.), is the Associate Dean (Research and Academic Programs) and the Linda D. and Timothy J. O'Neill Professor of Global Health Law at Georgetown University Law Center in Washington, D.C. He is also a Professor of Public Health at the Johns Hopkins University in Baltimore, Maryland and a Visiting Professor at Oxford University. Robert Archer, M.A., is the Executive Director of the International Council on Human Rights Policy in Geneva, Switzerland. 
Certainly, governments and philanthropic organizations have responded to highly visible natural disasters, droughts, and famines - at least while the issue remains salient in the media. And there has been increased international assistance for high-profile health threats such as AIDS and pandemic influenza. Even factoring in these new investments, however, most OECD countries have not come close to fulfilling their pledges to donate 0.7 percent of Gross National Income per annum. ${ }^{6}$ Developed countries would have to invest an additional $\$ 100$ billion by 2015 to close the vast investment gap.7 WHO projects that these additional expenditures would save millions of lives every year. ${ }^{8}$

The question then arises, if States have the capacity to assist less developed states (while continuing to fulfill their obligations to the health of their own citizens) to what extent do they have a well-defined legal or ethical responsibility to do so? ${ }^{9}$ We claim that States have a responsibility to help, derived from international law, political commitments, ethical values, and national interest. However, international law does not enable States to operationalize this responsibility in specific cases and in a transparent manner. As a result, transnational cooperation by States tends to be ineffectual and inconsistent - although States can and sometimes do act effectively when ethical and legal responsibilities and commitments align with self-interest.

\section{Obligations Under International Law to Provide Assistance}

States recognize an obligation for international cooperation, but the extent of this obligation remains subject to continuing debate. The United Nations Charter includes among its purposes the achievement of international cooperation in solving international problems of an economic, social, cultural, or humanitarian character, and in promoting and encouraging respect for human rights and for fundamental freedoms for all without distinction as to race, sex, language, or religion. ${ }^{10}$ International human rights law expresses a universal duty to assure human dignity and health. The Universal Declaration of Human Rights guarantees respect for economic, social, and cultural rights, considering them "indispensable for human dignity, and proclaims that they should be realized "through national effort and international cooperation."11

A State's duty of international cooperation and assistance is derived from a number of international legal sources, including the International Covenant on Economic, Social and Cultural Rights (ICESCR), the human right to health, and the International Health Regulations (IHR), discussed below.
International human rights law expresses a universal duty to assure human dignity and health. The Universal Declaration of Human Rights, which is widely considered to be part of customary international law, guarantees respect for economic, social, and cultural rights, considering them "indispensable for human dignity," and proclaims that they should be realized "through national effort and international cooperation."12

\section{International Covenant on Economic, Social and Cultural Rights}

States that have ratified the ICESCR have made a formal legal commitment to help one another: each State Party "undertakes to take steps individually and through international assistance and cooperation, especially economic and technical, to the maximum of its available resources, with a view to achieving progressively the full realization of the rights recognized...by all available means, including particularly the adoption of legislative measures." 13 Although the ICESCR provides for progressive realization and acknowledges the limits of available resources, it also imposes immediate obligations. State Parties to the Convention "undertake to guarantee" that relevant rights "will be exercised without discrimination."

More importantly, the obligation "to take steps" is not qualified or limited. General Comment 3 states, " $[\mathrm{W}]$ hile the full realization of the relevant rights may be achieved progressively, steps towards that goal must be taken within a reasonably short time... Such steps should be deliberate, concrete and targeted...."14 The General Comment contains detailed standards for implementing the right to health including the duty to: (i) adopt framework legislation (e.g., a national strategy and plan of action, with sufficient resources); (ii) identify appropriate right to health indicators and benchmarks (e.g., to monitor improvements in community health); and (iii) establish adequate remedies and accountability (e.g., access to courts, ombudsmen, or human rights commissions).

\section{The Human Right to Health}

The duty of international cooperation is often framed specifically in the context of a universal right to health. The International Bill of Human Rights, as well as numerous U.N. and regional human rights treaties, proclaim the right to health. ${ }^{15}$ Many countries have also incorporated a right to health or health care in their domestic law. ${ }^{16}$ In affirming that human beings are entitled to the "highest attainable standard of physical and mental health," Article 12 of the ICESCR lists elements that are necessary steps for its realization: 
- reduction in stillbirths and infant mortality;

- healthy development of the child;

- improvement in environmental and industrial hygiene;

- prevention, treatment and control of epidemic, endemic, and occupational diseases; and

- creation of conditions to assure medical services in the event of sickness.

The ICESCR, therefore, defines health to include both physical and mental health and lists a range of objectives that need to be achieved in cooperation with the international community. ${ }^{17}$

The Committee on Economic, Social and Cultural Rights' General Comment 14 provides guidance on the normative content and States' international obligations concerning the right to health. ${ }^{18}$ Normatively, the Committee interprets the right to health inclusively. It extends not only to health care but also to the underlying determinants of health (e.g., potable water, sanitation, safe food and adequate nutrition, housing, healthy occupational and environmental conditions, and health information).

The right to health must be available in sufficient quantity; accessible to everyone without discrimination, including physical and economic availability; acceptable to different cultures, genders, age groups; and of adequate quality. The right to health, like all human rights, imposes three types or levels of obligations on States Parties: respect (refrain from interfering with the enjoyment of the right to health), protect (prevent third parties from interfering with the right to health), and fulfill (adopt appropriate legislative, administrative, budgetary, judicial, promotional, and other measures towards the full realization of the right to health).

\section{International Obligations}

As mentioned, all States Parties to the IESCR have a duty to take steps, individually and through international assistance and cooperation, especially economic and technical, towards the full realization of social and economic rights, such as the right to health. The Alma-Ata Declaration on Primary Health Care states that the existing gross inequality in health status is of common concern to all countries..$^{19}$ General Comment 14 declares that States commit to taking joint and separate action to achieve the full realization of the right to health. "Depending on the availability of resources, States should facilitate access to essential health facilities, goods, and services in other countries, wherever possible and provide the necessary aid when required." 20 They should also ensure that the right to health is effectuated through international agreements and international financial institutions, such as the International Monetary Fund and the World Bank. Economically developed States Parties have a special responsibility and interest to assist the poorer developing States through international aid and distribution of resources, such as safe and potable water, food, and medical supplies.

\section{The International Health Regulations}

The International Health Regulations (IHR, 2005) provide the most specific undertakings for international assistance in health. ${ }^{21}$ States that have ratified the IHR accept a duty to: (1) develop, strengthen,

\section{The right to health must be available in sufficient quantity; accessible to everyone without discrimination, including physical and economic availability; acceptable to different cultures, genders, age groups; and of adequate quality.}

and maintain the capacity of their public health services to detect, assess, notify, and report events; and (2) respond promptly and effectively to public health risks and emergencies of international concern. ${ }^{22}$ The World Health Assembly urged Member States to "mobilize the resources necessary" and to provide support upon request "in the building, strengthening and maintenance of public health capacities." ${ }^{23}$ These principles are reflected in the IHR, which requires Member States to:

- collaborate in implementation (Art. 5.2);

- assist developing countries in particular (Art. 5.3);

- provide technical cooperation and logistical support with assistance from the Director General (Art. 6.6),

- help mobilize financial resources for developing countries (Art. 6.7).

During public health emergencies of international concern, WHO is empowered to mobilize international assistance. States "should provide, to the extent possible, support to WHO-coordinated response activities." (Arts. 13.4, 13.5). ${ }^{24}$ 


\section{Political Commitments to Assist Poor States in Need}

Critics say that political obligations are not binding in practice and are therefore ineffectual. There is some truth to this criticism. Treaties do not specify how much States should give, to whom, and in what circumstances; nor have States developed operational principles that would enable them to negotiate transparently the contributions that each should make in specific cases. However, the fact that States have formally agreed by treaty to assist poorer countries is significant in that it provides a foundation for a system of international cooperation that may in time have practical and operational effect.

Coinciding with their assumed legal obligations, States have made political promises to provide assistance and cooperate with one another to achieve humanitarian and human rights objectives. Although such commitments fall short of legal undertakings, they generate obligation by implicating the credibility of the governments involved and raising expectations of recipient countries.

In the United Nations Millennium Declaration, Heads of State recognized that "in addition to our separate responsibilities to our individual societies, we have a collective responsibility to uphold the principles of human dignity, equality and equity at the global level. As leaders, we have a duty to all the world's people, especially the most vulnerable...." The Declaration goes on to state that "global challenges must be managed in a way that distributes costs and burdens fairly in accordance with basic principles of equity and social justice...."25 The Millennium Development Goals, attached to the Declaration and adopted as targets by most States, affirm the general commitment of States to assist one another internationally to promote development, particularly in relation to health. Goal 8 notably emphasizes the importance of developing a global partnership for development. ${ }^{26}$

The Group of Eight leading industrialized nations (G-8), in response to the Millennium Development Goals, has committed itself to "work to ensure that bilateral and multilateral assistance to help mobilize capital and expertise to accelerate growth and free up resources for productive use by people in developing countries." The purpose of this declaration is to help eradicate poverty. ${ }^{27}$

In addition to these general commitments to global development, States have made promises relating to specific health issues. In November 2001, Member States of the World Trade Organization (WTO) promulgated a Declaration relating to the Agreement on Trade-Related Aspects of Intellectual Property
Rights (TRIPS) and Public Health. ${ }^{28}$ In this Declaration, States recognized that resource-poor countries face major public health problems (e.g., HIV/AIDS, tuberculosis, and malaria) and called for "flexibilities" to protect the public's health by promoting access to essential medicines. In separate initiatives, industrialized countries have undertaken to provide funding for these public health conditions. The G-8 pledged to help reduce the global HIV/AIDS resource gap nationally and internationally, for example by fully funding the Global Fund to Fight AIDS, Tuberculosis and Malaria, the Global Plan to Stop TB, and the Gleneagles commitment to Universal Access to HIV/ AIDS treatment by 2010. ${ }^{29}$ Through the Gleneagles Agreement the G-8 agreed to double international aid to Africa by 2010.30 Developed countries have made similar promises for vaccine development. ${ }^{31}$

In summary, a majority of States has made legal undertakings and political commitments to help protect the health of people in all countries (not just their own). Often framed in general terms, the underlying promises of these undertakings and commitments have not been fulfilled. Although a State's primary obligation is to the people within its jurisdiction, it has a responsibility (and sometimes a legal obligation) to assist needy countries and populations abroad provided it has the resources to do so.

\section{Global Justice: An Ethical Justification for International Cooperation}

One may ask why States have voluntarily entered into agreements and made political promises to offer international assistance on matters of health. Part of the answer is that governments and most political leaders understand that they have ethical responsibilities to those who are less fortunate at home and abroad. For one thing, their electorates may hold them accountable if they behave unjustly. For another, political authorities incur risks and costs if they fail to address social problems - and this is true increasingly when they ignore visible suffering among people in poor countries. Finally, many officials and political leaders may feel personally a moral impulsion to act. The "common concern of mankind" is a powerful ethical force in any locale. ${ }^{32}$

Human rights law provides an authoritative, complete framework of officially recognized ethical principles that address issues of global equity. As noted, human rights norms need to be developed and refined to make clearer the international obligations owed by States. Still, for political leaders and governments, human rights create common space for negotiation and dialogue on issues of transnational cooperation. The framework's ability to provide a shared interna- 
tional language of negotiation in this area gives it tremendous potential value.

Similarly, global health is a particularly favorable area for the development of effective global cooperation. ${ }^{33}$ First, patterns of systematic disadvantage are evident and well documented. United Nations health agencies, national governments, NGOs, and philanthropic organizations have demonstrated the striking disparities in socioeconomic status and health that exist around the globe. ${ }^{34}$ Key health indicators such as infant deaths, morbidity, and premature mortality are significantly higher in developing countries as compared to developed countries. ${ }^{35}$

Second, richer countries have the ability to intervene effectively, with clear positive effects on a wide range of diseases and causes of disease. Developed countries have the expertise and financial wherewithal to assist others without harming the health of their own citizens. At the same time, poor countries lack the capacity to protect the basic health needs of their own citizens.

Third, and crucially, the public strongly supports the ideal of global cooperation. Global action to ameliorate poverty and disease is not controversial. Disease is not generally considered to be a "moral fault" problem, although advocates have blamed rich countries for helping to create the conditions of poor health in the developing world. Intervention to reduce its incidence also is not generally regarded - either by donor or receiving populations - as a matter that involves political interference. The fact that international cooperation in matters of health is generally perceived to be politically accepted explains why governments have been able to cooperate in support of global vaccination programs and emergency action to deal with potential pandemics such as SARS. ${ }^{36}$

\section{National Interest, Sovereignty, and a Broader Freedom}

As already noted, however, the first and primary obligation of governments is to its citizens. Where international human rights law is general and somewhat imprecise about the transnational obligations of governments, it is specific and detailed about their national obligations. Politically, too, governments have a direct and immediate interest in seeing to the needs of their own people first, particularly if they wish to be re-elected. Legal principles and State claims to national sovereignty only reinforce this imperative. Finally, public attitudes tend to drive governments in the same direction. Most political leaders are vulnerable to public and media criticisms that they neglect domestic or local needs when they prioritize larger issues. For all these reasons, in practice, effective international action is likely to be successful when its objectives coincide with national interest, or are understood to do so.

In this context, the wider adoption of human rights language and the assertion by some countries that their foreign policies will be influenced or conditioned by ethical considerations are highly relevant. National interest may be broadly or narrowly conceived. In a world that is increasingly interdependent, it is becoming evident that a narrow calculation of national interest (in terms of measurable short-term advantage) may actually put at risk a country's long-term interests. Numerous examples could be cited. An obvious one is global warming: every economy may gain competitive advantage by postponing interventions that reduce energy consumption (provided that other economies act), but the net effect of inaction may profoundly (if unevenly) harm the public health and environmental interests of all countries. The same logic applies to many other instances where global competition occurs or cooperation is required to address risk - from trade, to the sharing of water resources, the control of disease, and the management of global goods.

Management of risk is likely to be a crucial component of efforts in richer countries to build broad models of national interest that feature ethically defensible outcomes. Governments must be able to strongly justify policy initiatives that generate immediate costs for their voters, but not immediate benefits. In some cases, electorates in rich countries may be persuaded that long-term benefits will accrue to them, which outweigh short-term costs. In most cases, however, persuasive arguments for spending now, without return, will rely on risk. Arguments for environmental reforms (to slow or stabilize global warming, for example), or international action to stop the spread of disease or conflict, or reduce poverty or raise standards of education, all rely on the premise that failure to act will increase the risk of illness, conflict, or economic disorder, or will generate future harms that will threaten the quality of life of the next generation.

A broader vision of national interest would lead governments to make robust and ongoing commitments to international assistance and cooperation across a range of global health issues. Under the IHR, States Parties have the duty to develop, strengthen, and maintain core public health capacities to detect, assess, notify, and report events, and to respond promptly and effectively to public health risks and emergencies of international concern (Arts. 5[1], 13[1], Annex 1). ${ }^{37}$ Global health protection relies on the ability of national and sub-national governments to engage in speedy and accurate surveillance and response to health threats. ${ }^{38}$ The desire to build pub- 
lic health infrastructures, however, is hollow without adequate resources for poor countries. No country can insulate itself from infectious diseases or other global health threats. It is thus in the government's self-interest to provide technical and financial assistance to build capacity in poorer countries. matter for States. It has been argued that States have a "responsibility to protect" - a duty to intervene abroad when a national government fails to protect its people or puts them at risk. ${ }^{41}$ The United Nations has explored the duties of States to intervene, in rather extreme and strictly defined circumstances, to meet demonstrable needs for health and security, even when the host country refuses. ${ }^{42}$ Although the debate has focused on armed interventions that use force to protect human rights, the argument is likely to be most relevant where intervention is with the consent of the government concerned. If the "responsibility to protect" principle is accepted, it will imply a shift in diplomatic and legal thinking: the principle of sovereignty will give ground to human need. This would enlarge the political space available for developing forms of consensual international cooperation. cable, it poses a general threat to life and prosperity - a risk that increases exponentially with any decline in health management. Where sickness and death rates are endemic, the effects on economic development and security are long term and pervasive. Pandemic influenza will likely destabilize world trade. ${ }^{39}$ For these reasons, developed countries have recharacterized the HIV/AIDS pandemic as a national security threat. ${ }^{40}$

Of course, the risks are uneven. Although cooperation on global vaccination programs and the SARS crisis has been rather effective, maternal health remains a significant public health crisis. Very large numbers of women in Africa die or suffer severe injury during childbirth from conditions that are well understood and routinely managed in richer countries. No international campaign has effectively addressed this problem - no doubt because in part poor maternal health poses no external risk to others outside affected countries.

Sovereignty has always been a sensitive issue whenever countries address the question of intervention abroad, and particularly when States use force to impose on other States. The United Nations system was constructed to manage risks of this kind. When a country is not able, or is unwilling, to protect its own population, the responsibility of other countries to assist or protect that population has been difficult to define. Is their duty of care conditioned by the behavior of the national government in question? Are national governments entitled, on grounds of sovereignty, to refuse assistance from abroad? In what circumstances might the duty of third party governments to assist stricken populations override sovereignty?

Efforts have been made to clarify these issues recently, although this remains an extremely sensitive

\section{International Assistance and the Problem of Global Governance}

Developing inclusive and effective international collaboration is extremely difficult to achieve both generally and in particular cases. The international community has thus far failed to improve global health, as demonstrated by the lack of success of "Roll Back Malaria," 43 and the failure of the World Health Organization's " 3 by 5 " initiative, which aims dramatically to expand access to antiretroviral therapies for HIV.44 While States acknowledge their general commitment to a just international order, they remain unwilling to say that their decisions to assist other States and societies abroad are more than elective. In general, they wish to retain their freedom and to choose when to assist and to determine what kind of assistance is to be offered. As long as this is so, international assistance will remain uneven and inadequate.

\section{A Failure of Moral Imagination}

It may not be feasible to devise methods of global governance to overcome these intractable problems. ${ }^{45}$ Still, WHO and Member States could take steps to agree on procedures for assessing the burdens faced by States both in terms of ongoing needs and in public health emergencies. This could include criteria for assessing contributions that States should make to international assistance based on the level of need and the resources available to meet those needs. One of us, moreover, has proposed a Framework Convention on Global Health, which could be a governance vehicle for international cooperation and assistance. ${ }^{46}$

What is missing in global health is a robust and equitable framework for assessing international respon- 
sibilities - although it appears like a failure of moral imagination. ${ }^{47}$ In the longer term, the power of ethical values and notions of human solidarity should not be underestimated. Given the increasing range of issues that require global management and cooperation, governments may find they are obliged to develop and operationalize principles of equity and fairness that will permit them to establish higher levels of health and security across the world.

References

1. World Health Organization, World Health Statistics, 2007, available at <http://www.who.int/whosis/en> (last visited September $4,2007)$.

2. D. R. Gwatkin and M. Guillot, The Burden of Disease Among the Global Poor: Current Situation, Future Trends, and Implications for Strategy, World Bank, Washington, D.C., 1999.

3. World Health Organization, The World Health Report 2000, World Health Organization, Geneva, 2000, at Annex Table 8 (latest available data from 1997); G. F. Anderson, P. S. Hussey, and B. K. Frogner et al., "Health Spending in the United States and the Rest of the Industrialized World," Health Affairs 24 (2005): 903-914.

4. World Health Organization, "National Influenza Pandemic Plans," available at <http://www.who.int/csr/disease/influenza/ nationalpandemic/en/index.html> (last visited September 4, 2007).

5. L. O. Gostin and B. E. Berkman, "Pandemic Influenza: Ethics, Law, and the Public's Health," Administrative Law Review 59 (2007): 121-75.

6. A. Shah, "Government Cutting Back on Promised Responsibilities: Rich Nations Agreed at U.N. to 0.7\% of GNP to Aid," April 8, 2007, available at <http://www.globalissues.org/TradeRelated/Debt/USAid.asp\#RichNationsAgreedatUNto07> (last visited September 4, 2007).

7. U.N. Millennium Project, "The Costs and Benefits of Achieving the Millennium Development Goals," in The Overview Report: A Practical Plan to Achieve the Millennium Development Goals (2005), available at <http://www.unmillenniumproject.org/ documents/overviewEng55-65LowRes.pdf> (last visited September 4, 2007)

8. R. Labonte and T. Schrecker, "Foreign Policy Matters: A Normative View of the G8 and Population Health," Bulletin of the World Health Organization 85 (2007): 185-91.

9. L. O. Gostin, "Why Rich Countries Should Care About the World's Least Healthy People," JAMA 298 (2007): 89-92; L. O. Gostin, "Meeting the Survival Needs of the World's Least Healthy People: A Proposed Model for Global Health Governance," JAMA 298 (2007): 225-28.

10. Charter of the United Nations, Articles 3 and 54, available at $<$ http://www.un.org/aboutun/charter/> (last visited September $7,2007)$.

11. Id., at article 22 .

12. Id.

13. See Charter of the United Nations, supra note 10, at Article 21. Similar language can be found in other treaties, such as the Convention on the Rights of the Child, "State Parties shall undertake such measures to the maximum of their available resources and, where needed, within the framework of international cooperation." Convention on the Rights of the Child, G.A. Res. 44/25, Art. 4 (September. 2 1990).

14. U.N. Economic \& Social Council [ECOSOC], General Comment 3: The Nature of States Parties' Obligations, U.N. Doc. E/1991/23, annex III at 86 (Fifth session, 1990).

15. See, e.g., Charter of the United Nations, supra note 10, at Article 56; U.N. Declaration of Human Rights, Article 25, available at <http://www.un.org/Overview/rights.html> (last visited September 7, 2007).
16. E. D. Kinney and B. A. Clark, "Provisions for Health and Health Care in the Constitutions of the Countries Around the World," Cornell International Law Journal 37 (2004): 285-355.

17. U.N. International Covenant on Economic, Social and Cultural Rights, Article 12, available at <http://www.unhchr.ch/html/ menu3/b/a_cescr.htm > (last visited September 7, 2007).

18. U.N. Economic \& Social Council [ECOSOC], General Comment 14, The Right to the Highest Attainable Standard of Health, U.N. Doc. E/C.12/2000/4 (Twenty-second session, 2000).

19. Declaration of Alma-Ata, International Conference on Primary Health Care, Alma-Ata, USSR, September 6-12, 1978, available at <http://www.who.int/hpr/NPH/docs/declaration_almaata. cpdf $>$ (last visited September 4, 2007).

20. U.N. Economic \& Social Council [ECOSOC], General Comment 14: The right to the highest attainable standard of health, U.N. Doc. E/C.12/2004/4 (Twenty-second session, 2000).

21. D. M. Fidler and L. O. Gostin, "The New International Health Regulations: An Historic Development for International Law and Public Health," Journal of Law, Medicine छ Ethics 34, no. 1 (2006): 85-94.

22. World Health Organization, Fifty-Eighth World Health Assembly, Revision of the International Health Regulations, W.H.A. Doc. 58.3 (May 23, 2005).

23. World Health Organization, Fifty-Eighth World Health Assembly, Revision of the International Health Regulations, Articles 5(1) and 13(1), annex 1, W.H.A. Doc. 58.3 (May 23, 2005).

24. Id., at Articles 13(4) and 13(5).

25. U.N. Millennium Declaration, available at <http://www.ohchr. org/english/law/millennium.htm> (last visited September 4, 2007).

26. U.N. Millennium Development Goals, available at <http://www. un.org/millenniumgoals/> (last visited September 4, 2007).

27. The White House, "G-8 Action Plan on Poverty," available at <http://www.whitehouse.gov/news/releases/2004/06/200406 09-35.html> (last visited September 7, 2007).

28. World Trade Organization, Ministerial Declaration on the TRIPS Agreement and Public Health, WT/MIN(01)/DEC/2, 41 I.L.M. 746 (2002); see C. M. Correa, Implications of the Doha Declaration on the TRIPS Agreement and Public Health, WHO/EDM/PAR/2002.3, World Health Organization, EDMSeries no. 12, 2002.

29. Statement of the Civil G-8 HIV/AIDS Round Table, available at <http://www.interaction.org/files.cgi/5204_HIV-AIDS Statement_from_Civil_G8_NGO_Forum_7-06.pdf $>$ (last visited September $\overline{4}, 200 \overline{7}$ ).

30. G-8 Gleneagles Agreement for Africa, 2005, available at $<\mathrm{http}: / /$ www.fco.gov.uk/Files/kfile/PostG8_Gleneagles_Africa,0.pdf $>$ (last visited September 4, 2007).

31. G-8 Summit 2006, "Fight Against Infectious Diseases," "Center for Global Development," "G-8 Progress on Advance Market Commitments for Vaccines," (reporting that Canada, Italy, the U.K., the U.S., and Russia support AMCs, particularly for pneumococcal infections), available at <http://en.g8russia.ru/> (last visited September 7, 2007).

32. G.A. Res. 43-53 (December 1998) (although covering climate change directly, the declaration focuses on principles of equity basic to mankind).

33. M. Powers and R. Faden, Social Justice: The Moral Foundations of Public Health and Health Policy (New York: Oxford University Press, 2006).

34. World Health Organization, "Commission on Social Determinants of Health," available at <http://www.who.int/social determinants/en/> (last visited September 4, 2007).

35. D. Satcher, "Eliminating Global Health Disparities," JAMA 284 (2000): 2864

36. Predictably, there are exceptions. Local resistance in Nigeria to the vaccination program against polio, due to political suspicion, led to a recrudescence of the disease two years ago. Also in Africa, a mix of local suspicion and medical insensitivity appear to have obstructed international interventions to manage outbreaks of Ebola. See C. Abraham, "Western Medicine 
Doesn’t Have All the Answers," New Scientist (July 21, 2007): 35-37.

37. See World Health Organization, supra note 23.

38. Public Health Agency of Canada, Learning From SARS Renerwal of Public Health in Canada: A Report of the National Advisory Committee on SARS and Public Health, Public Health Agency of Canada, October 2003, available at <http://www. phac-aspc.gc.ca/publicat/sars-sras/naylor/index.html> (last visited September 4, 2007); L. O. Gostin, R. Bayer, and A. L. Fairchild, "Ethical and Legal Challenges Posed by Severe Acute Respiratory Syndrome: Implications for the Control of Severe Infectious Disease Threats," JAMA 290 (2003): 3229-37.

39. U.S. Department of State, "The United States and Developing Countries: Partnering for Growth," U.N. General Assembly 2006-2007 (September 14, 2006), available at <http://www. state.gov/documents/organization/72352.pdf > (last visited September 7, 2007).

40. H. Feldbaum, K. Lee, and P. Patel, "The National Security Implications of HIV/AIDS," PLoS Medicine 3, no. 6 (2006): 774-78.

41. The Responsibility to Protect: Report of the International Commission on Intervention and State Sovereignty, 2001, available $a t<\mathrm{http}$ ://www.iciss.ca/menu-en.asp> (last visited September $4,2007)$.

42. U.N. High Level Panel on Threats, Challenges and Change, A More Secure World: Our Shared Responsibility (2004), available at <http://www.un.org/secureworld/> (last visited September 4, 2007); The Secretary-General, In Larger Freedom: Towards Development, Security and Human Rights for All, September 2005, available at <http://72.14.209.104/ search?q=cache:tQw2EgyZ024J:www.un.org/largerfreedom/ executivesummary.pdf $+\mathrm{UN}+\mathrm{In}+$ Broader + Freedom $\& \mathrm{hl}=\mathrm{en} \& \mathrm{~g}$ $\mathrm{l}=$ us\&ct=clnk\&cd=1\&client=safari $>$ (last visited September 4 , 2007).

43. Anonymous, "Reversing the Failures of Roll Back Malaria," The Lancet 365 (2005): 1439

44. Anonymous, "Predicting the Failure of 3 by 5," The Lancet 365 (2005): 1597.

45. A. Taylor, "Governing the Globalization of Public Health," Journal of Law, Medicine E Ethics 32, no. 4 (2004): 500-16; S. Burris, "Governance, Microgovernance and Health," Temple Law Review 77, no. 2 (2004): 335-58; D. P. Fidler, "Architecture Amidst Anarchy: Global Health's Quest for Governance," Global Health Governance 1 (2007): 1-17.

46. L. O. Gostin, "Meeting Basic Survival Needs of the World's Least Healthy People Toward a Framework Convention on Global Health," Georgetown Law Journal (Forthcoming 2008); See Gostin, supra note 9.

47. S. R. Benatar, "Moral Imagination: The Missing Component in Global Health," PLoS Medicine 2, no. 12 (2005): 1207-10. 